University of Massachusetts Amherst

ScholarWorks@UMass Amherst

\title{
Flipping an Academic Library Collection: A Path to a Global Open Scholarly Commons
}

Christine N. Turner

University of Massachusetts Amherst, cturner@library.umass.edu

Marilyn S. Billings

University of Massachusetts Amherst, mbillings@library.umass.edu

Follow this and additional works at: https://scholarworks.umass.edu/librarian_pubs

Part of the Scholarly Communication Commons

\section{Recommended Citation}

Turner, Christine N. and Billings, Marilyn S., "Flipping an Academic Library Collection: A Path to a Global Open Scholarly Commons" (2019). Collection Management. 74.

https://doi.org/10.1080/01462679.2019.1582391

This Article is brought to you for free and open access by the University Libraries at ScholarWorks@UMass Amherst. It has been accepted for inclusion in University Libraries Publication Series by an authorized administrator of ScholarWorks@UMass Amherst. For more information, please contact scholarworks@library.umass.edu. 


\section{"Imagining the Future Academic Library Collection" Collection Management Special Issue}

TITLE: Flipping an Academic Library Collection: a path to a global open scholarly commons SHORTENED TITLE: Flipping an Academic Library Collection

BY: Christine N. Turner, University of Massachusetts Amherst, and Marilyn S. Billings, University of Massachusetts Amherst 


\section{INTRODUCTION}

Library collection activities have certainly changed since automation took hold, and the shift from physical to digital collections has accelerated with the development of more and more robust networks. Journal and book publishing models have multiplied, with libraries bearing higher and higher subscription and purchase costs. Public expectations for access to online networked information have also increased, creating a divide between what resources a university library can afford and what publishers offer for payment, or toll access. The emergence of the open access movement in the early 2000's was in step with, and supported, expectations that people should be able to freely use online content without harming an author's rights to control the integrity of their works. Libraries have always been critical players in the information marketplace, and they've contributed to multiple means of shifting the cost of information access away from the user.

The University of Massachusetts Amherst Libraries (the Libraries), are the public academic research libraries for the Commonwealth's flagship campus. UMass Amherst is a Carnegie Research 1 Doctoral University with approximately 28,500 full-time equivalent students. The Libraries are a member of the Association of Research Libraries (ARL) with a staff of 130 and a collection acquisitions budget of $\$ 8,472,000$. They have a fundamental interest in providing open access $(\mathrm{OA})$ to the scholarship produced by their researchers and to the scholarship that their researchers need to do their work. The Libraries are part of the scholarly communication system comprised of individual works, collections, authors, publishers, digital infrastructure and a variety of support organizations. How the Libraries have invested in the 
various parts of this system is illustrative of the opportunities and challenges facing academic libraries more broadly.

Reviewing their related activities over the past ten years, including the "The $2.5 \%$ Commitment" benchmarking exercise in 2017, led the Libraries to anticipate the composition and characteristics of their future collections. In addition to their collections of materials that were once almost entirely published by and acquired from providers outside the University, the Libraries now have a significant body of work from unique special collections and University scholarship, growth in what Lorcan Dempsey refers to as the "inside-out Library" (Dempsey $2016,1)$. The evolving make-up of their collections have been achieved through changes in administration and staffing, infrastructure development, and outreach to campus and beyond. The Libraries' collections reflect UMass Amherst faculty's research and teaching needs and the scholarship they produce. Through continued and accelerated investments, the Libraries' future collections will reflect a higher proportion of unique and special collections, and open access content.

\section{ADMINISTRATION AND STAFFING}

As early as 2008, the Libraries' administration understood that the complex scholarly communication system needed librarian, faculty and researcher expertise to succeed. Librarians, faculty and the university press director participated in professional development opportunities, such as the ARL/ACRL Scholarly Communication Institute and regional and national workshops, gaining new knowledge and expertise. Shortly thereafter the Director of Libraries created a new Scholarly Communication (SC) department in the Libraries. The 
Scholarly Communication \& Special Initiatives Librarian initiated a pilot for a two year Institutional Repository Resident Librarian position (co-funded with the Office of Research, Center for Teaching and Faculty Development and the Graduate School) in 2008. A Copyright and Information Policy Librarian joined the department in 2012. The copyright librarian has been an influential advocate for campus authors' rights, the campus Open Access Policy and national policies that favor open access scholarship. Throughout this period, the SC librarians were monitoring national discussions about open education. In 2011, the Libraries began offering grants to campus faculty for using or developing open educational resources (OER) in their courses, and by 2013 the Libraries were recognized as a national leader in the open education movement. They added a new position, Digital Projects Manager, to the SC department. This librarian's responsibilities include administering the Open Education Initiative (OEI) grants, leading workshops, developing a grant assessment program and sharing open education developments within the campus and around the globe. In 2016, the two year Institutional Repository Resident Librarian model was converted to a permanent position, the Open Access and Institutional Repository Librarian, to ensure the continuity of institutional repository (IR) support and development. In 2017, the Libraries recognized that their scholarly communication program, which focused primarily on campus scholarly works, needed more intentional integration with the OA support provided by other parts of the organization. The Libraries envisioned a new position that would showcase their strategic goals and values for more open and accessible collections and shepherd the realignment of their future investments in OA. The Acquisitions and Scholarly Communication Librarian moved from the Acquisitions to 
the SC department in the fall of 2017. The SC department had grown from a staff of 2 in 2008 to five in 2018, further signaling a shift of personnel resources towards OA.

As the SC department grew to support local scholarship and collections, so did Special Collections and University Archives (SCUA) department staff. A department of 6 full-time staff ten years ago now has 9 full-time staff to support growing unique physical and digital collections and the digital infrastructure which underpins them. The SC and SCUA departments, with their foci on original and unique digital collections, each added three new positions between 2008 and 2018. Over the same period cataloging and processing functions, which had focused on externally produced physical and digital resources, experienced a reduction of sixteen positions. This reduction of a traditional technical services staff also coincided with streamlining and outsourcing of services for predominantly digital collections.

Since 2016 there has been significant organizational and policy change in the Libraries. The Dean of Libraries joined UMass Amherst in August of 2016, and after reflecting on staffing levels, he created two new leadership positions. The Associate Dean for Content and Discovery was appointed in the summer of 2017 and the Associate Dean for Library Technology was appointed in the summer of 2018. By increasing the number of associate deans from one to three, the Dean brought more dedicated leadership to the collections and digital infrastructure areas. The Dean also reallocated resources and established the Digital Scholarship Center where staff actively engage with faculty on digital projects and provide a one-stop referral to other library services that are available in the Digital Media Lab, Research Services, Scholarly Communication and other areas of the Libraries. 
As consortial buying plans, acquisitions budget allocations for monographic purchases and librarians' specialty assignments were changing, the Libraries' leadership initiated a review of collections governance and policies. A task force reviewed seven collections-related policies and recommended updating, consolidating and modifying them into five policies: Collections Priorities, Digital Preservation, Electronic Resource Usage, Gifts and Special Collections. The Collection Priorities provide overarching areas of foci and values consistent with the Libraries' Strategic Plan. Priorities include investing in unique and open collections, and collaborating with partners to expand access to resources. These priorities will guide the future development of the Libraries' collections.

\section{COLLECTIONS AND INFRASTRUCTURE}

Around the time of the financial crisis of 2008, the Libraries started directing more of their financial and staff resources to increasing and making their unique special collections and university scholarship openly accessible. Their acquisitions budget was stagnant and the costs of subscription resources continued to increase about 5\% annually. Monograph and textbook costs, both for print and online editions, were also on an upward trajectory. Given what publishers were charging for editorial, production, distribution/hosting and associated services, and a flat acquisitions budget, changes to how the Libraries developed their collections was a matter of survival.

Purchasing published materials was historically the norm for the Libraries, but they also cataloged and housed university archives and collections donated to them. Their signature special collection is the personal papers of W.E.B. Du Bois which were donated to the Libraries 
in 1973. SCUA is the home of the Du Bois papers, and it broadly collects historical and cultural materials consistent with the themes of social change in America, New England with an emphasis on Massachusetts, innovation and entrepreneurship, and the University of Massachusetts Amherst community. The transition from physical to digital collections began in 2009 with the digitization of the Du Bois papers. This grant-funded project further developed into the digital repository, Credo, which provides free online access to the complete W.E.B. Du Bois and Horace Mann Bond papers, as well as dozens of other complete collections (http://credo.library.umass.edu/). Credo uses the Fedora repository open source software, and its development demonstrates an investment in the open source software community.

Nascent efforts to create institutional repositories (IRs) began in the early 2000 s as a response to the dramatic increase in journal subscription costs. The Scholarly Communication \& Special Initiatives Librarian evaluated several possible options and proposed to license bepress' Digital Commons software. The Administration accepted this proposal, thus establishing ScholarWorks@UMass Amherst (ScholarWorks) as the UMass Amherst IR in July 2006. A collaboration with the Graduate School on Electronic Theses and Dissertations (ETDs) produced one of the first collections in ScholarWorks. After developing workflows and conducting a successful pilot program in 2008, the Graduate School began requiring students to deposit their thesis or dissertation into ScholarWorks. The Libraries then took the decisive steps of cancelling their subscription to the proprietary theses \& dissertations database, and joining the Networked Digital Library of Theses and Dissertations (NDLTD) (http://www.ndltd.org/). Between ScholarWorks and NDLTD, the Libraries enhanced theses and dissertation discoverability and access through OA repositories and commonly available search engines, 
such as Google. The ETDs in ScholarWorks are some of the most heavily downloaded materials in the IR, demonstrating the impact that OA has on the dissemination of scholarship.

The need to address the high cost of textbooks and other curricular materials also came to the fore as the open education movement coalesced in 2010. The Libraries established their OEI grant program (https://www.library.umass.edu/oer/open-education-initiative/) with the Provost's Office, in partnership with the offices of Teaching Excellence and Faculty Development (TEFD), Instructional Innovation, and Academic Information Technology. Initially the grants were awarded to faculty who proposed to reduce the cost of textbooks for students. Some projects were a combination of free web materials, licensed library resources and OER, and others were newly created OER. Since 2016 the OEI has prioritized proposals to adopt, adapt or create OER in preference to the previous affordability projects. Of the 10 recipients of grants in 2018, six of the projects were to create original, openly licensed textbooks. Subjects covered in these textbooks include landscape history, beekeeping, project management and professional development.

As the Libraries developed the means of producing and providing open access to the University's scholarship, teaching materials and special collections, it also dedicated financial and staff resources to OA resources, systems and organizations outside the University. The Libraries were early supporter-members of arXiv, BioOne, BioMed Central, and the Sponsoring Consortium for Open Access Publishing in Particle Physics (SCOAP3). The Libraries gave financial support to OA projects such as Knowledge Unlatched, the Open Library of the Humanities (OLH) and the open repositories HathiTrust and the Internet Archive. Library staff contributed review, metadata and processing services to the open repositories. Each of these initiatives funded 
their open content through different means, and the models evolved, some using article processing charges and some using crowdsourcing (Reinsfelder and Pike 2018, 3-4). The approaches remain experimental, as the means of most effectively altering the scholarship economy is still in flux. The general approach used by UMass Amherst has been to support initiatives from which their community and the Libraries would benefit, and to participate in organizations which have supported OA in myriad ways.

The Libraries' collection development activities (for third party publications, UMass Amherst scholarship and local unique collections) have been connected to the needs of their local communities and academic library consortia collaborations. In addition to their role as a member of the five campus University of Massachusetts system, the Libraries participate in sharing and/or joint purchasing opportunities offered by Five College Libraries (Amherst College, Hampshire College, Mount Holyoke College, Smith College and UMass Amherst), Boston Library Consortium (BLC), and Northeast Research Libraries (NERL), among others. These affiliations, ARL membership and University accreditation require regular data gathering and reporting on collection materials and spending, but until 2017 there had been no systematic accounting of the Libraries' investments in open access materials and infrastructure.

In "The $2.5 \%$ commitment" David Lewis suggested that $2.5 \%$ of the collection budgets should be devoted to an open scholarly commons (Lewis, September 2017). He provided the basis of an inventory - including open source software and the organizations that support them, repositories, tools, preservation organizations, open educational resources and advocacy organizations - as categories of what to count towards that financial investment (Lewis, September 2017, 3). Furthermore, he suggested a potential process for collecting data about 
the types and amounts of investments libraries make (Lewis 2017,4). Then David Lewis and Michael Roy worked together to develop the list of open source investment items and to recruit academic libraries to participate in their survey (https://scholarlycommons.net/2017/12/10/cni2017/).

UMass Amherst Libraries was one of 35 libraries to respond to the " $2.5 \%$ Commitment and Open Data Collection Tool Project". The Scholarly Communication \& Special Initiatives Librarian shared the list (https://scholarlycommons.net/the-list/) with library administrators and staff, and the Acquisitions and Scholarly Communication Librarian collected and entered the data into the shared Google sheet. Personnel costs associated with open access activities were particularly fraught with ambiguity, and after consultation with Michael Roy, the librarians determined the personnel investment figures based on estimates of time for major job duties. The Acquisitions and Scholarly Communication Librarian consulted with nine colleagues to verify participation in specific items and to identify costs associated with them. This broad consultation was necessary because costs and payments were spread throughout the collections, operating and personnel/salary budget lines, and the associated work was performed across many departments. Costs and investments were not readily available, supporting Lewis' (August 2017, 6) observation that libraries' commitments to open access endeavors are not prioritized or coordinated.

The Libraries' participation in the Open Data Collection Tool Project generated discussion among library staff and administration about what constitutes open access investments, and how to calculate them. The Libraries tallied 3 investments in infrastructure, 16 in open content, 5 in organizations, as well as development of an IR, OA journal and book 
publishing services with staff support. The 2017 fiscal year OA investments constituted 3.69\% of the Libraries total budget, excluding staffing costs, and $4.61 \%$ of its collections budget. Both surpassed the $2.5 \%$ benchmark, and it brought into focus what the Libraries had contributed to the development of an open scholarly commons. For the first time it produced a monetary amount with which to compare to other academic library OA commitments. UMass Amherst librarians discussed participation in the project and issues it raised with others at David Lewis' and Michael Roy's presentation at the Coalition of Network Information (CNI) meeting in December 2017 (https://scholarlycommons.net/2017/12/10/cni2017/) and at meeting of Boston Library Consortium Heads of Collection Management the following Spring. Throughout this period of high level administration and policy review, benchmarking, and staffing changes, UMass Amherst librarians continued to build upon a foundation for an open scholarly commons. Librarians and archivists were nurturing relationships with researchers, administrators and scholars around the UMass community and advocating for contributions to the "open" vision. Though SCUA has a relatively small budget for acquiring new collections, librarians and archivists use their expertise and existing technical systems, with the benefits of digitization, preservation and broad access, to attract new special collection donations. Scholarly Communication staff have prioritized efforts to add UMass Amherst faculty, researcher and student works to ScholarWorks and have encouraged new OA scholarship through the administration of funds to support open access article, book and textbook publication. Following research and consultations, librarians recently changed the eligibility criteria for the UMass Amherst Supporting Open Access Research (SOAR) fund which provides reimbursement for article processing charges (APCs). The criteria now give preference to early 
career authors publishing with non-profit publishers who comply with open access best practices (https://doaj.org/faq\#seal). The SOAR Fund and the OEI grant requests have outnumbered the funds dedicated to them, demonstrating a clear need for additional financial support. Librarians continue to build alliances with faculty and administrators to increase the financial allocations to these initiatives from grants and other sources. While the Libraries and campus create unique digital collections and scholarship, they are focused also on developing the infrastructure upon which this content is managed, made discoverable and distributed through the broader commons. As Joseph and Shearer state, "the use of open source platforms, with appropriate community governance, is ... critical to ... preventing greater commercial control of scholarly content and associated services" (September 29, 2018, https://sparcopen.org/news/2017/elsevier-acquisition-highlights-the-need-for-communitybased-scholarly-communication-infrastructure/). SCUA's digital collections repository, Credo, is open source; librarians are investigating an alternative to the proprietary IR software (Digital Commons) it currently uses; the OEI uses Pressbooks, an open source plugin to WordPress that creates a book production content management system. Librarians are working with the campus Offices of Research and Engagement and Information Technology to implement a leading edge research information system that will enable greater exposure to campus scholarship, and they provide associated education and services for digital object identifiers (DOI), ISSN and ISBN assignment; open researcher and contributor IDs (ORCID) integration; and altmetrics. Significantly, the Libraries are also a beta partner in The Future of Libraries is Open (FOLIO) project to build an open source library services platform. 


\section{COMMUNITY ENGAGEMENT AND OUTREACH}

Campus outreach and education were keys to establishing the Libraries' scholarly communication program. Informal outreach activities by individual librarians were complemented by formal collaborations. The aforementioned partnerships with the Office of Research, TEFD and the Graduate School led to additional joint ventures with each of them. For example, the Office of Research and the Libraries produced workshops and provided infrastructure to assist researcher compliance with grant funder open access requirements. With TEFD, the Libraries collaborated to broaden faculty adoption of OER in their courses. As graduate students produce their ETDs, the Graduate School and the Libraries have promoted digital publishing ethics and best practices.

In fall 2014, campus leaders invited OA champion Peter Suber to discuss with faculty, researchers and Faculty Senate leadership the next steps they would need to take to adopt a Harvard-style OA mandate. The Faculty Senate had supported in 2009 a "Resolution on Scholarly Publishing"

(https://www.umass.edu/senate/sites/default/files/Resolution\%20on\%20Scholarly\%20Publishi ng-Sen.\%20Doc.\%20No.\%2007-035.pdf) which was limited in impact, however, since it only encouraged faculty, librarians, staff, and administrators to support and utilize new and innovative models of scholarly communication whenever possible. Scholarly communication librarians and Faculty Senate Research Council members then spearheaded a multi-year campus education effort about OA related topics, with the goal of gaining faculty support for a Harvard-style Open Access Policy 
SS\%2OPOLICY\%20-\%20SEN.\%20DOC.\%20NO.\%2016-044 1.pdf). Annual October OA Week

events highlighted emerging trends in digital scholarship by bringing national experts to campus. Librarians and campus partners co-sponsored workshops on copyright, data, and ETD issues. Librarians visited faculty in their departments to explain the OA policy and answer questions. Finally, with the leadership of the Faculty Senate Research Council Chair and support of the Libraries, faculty senators unanimously approved the policy in April 2016. As a result of this policy, Libraries staff had the justification required to add copies of campus researcher articles to the IR, thus increasing its open collections.

In a rapidly changing ecosystem, it is imperative for librarians to participate actively in organizations that share common interests, provide community, develop best practices and provide examples of new workflows. The Scholarly Communication \& Special Initiatives Librarian was a founding member of the ACRL New England Chapter Scholarly Communication Interest Group (SIG). Scholarly communication librarians established the annual Northeast Open Educational Resource (OER) Summit each spring, working with regional OER leaders to bring in regional and national experts to share best practices and conduct workshops. The Libraries were founding members of the Library Publishing Coalition (LPC [https://librarypublishing.org/]), and early members of the Open Textbook Network (OTN [https://research.cehd.umn.edu/otn/]). The LPC and OTN provide examples of active, collaborative communities with ample opportunities for professional growth and development in open access, open education and open pedagogy. The Scholarly Communication \& Special Initiatives Librarian was a member of the Advisory Board for the library publishing curriculum (2018, https://educopia.org/deliverables/library-publishing-curriculum), a 15 week course that 
educates and empowers librarians to meet local demands to launch and/or enhance scholarly publishing activities. Librarians were active in Scholarly Publishing and Academic Resource Coalition (SPARC [https://sparcopen.org/]) discussions about how to accelerate OA transformation. These engagements bolstered past infrastructure development, and they continue to spur new opportunities.

\section{REALIZING FUTURE COLLECTIONS}

With years of OA content and infrastructure development behind it, and a vibrant OA community around it, the Libraries and UMass Amherst campus continue to identify additional means of contributing to the global scholarly commons. Lewis' work (August, 2017), the Pathways to Open Access toolkit (2018, https://libraries.universityofcalifornia.edu/about/initiatives/scholarly-communication) from the University of California Libraries, OA2020 (https://oa2020.org/take-action/) and other initiatives serve as guides to the Libraries' next activities. Lewis notes:

What we, as the academic library community, want to create is an open scholarly commons that will be digital and distributed with colleges, universities, cultural heritage organizations, scholarly societies, foundations, and governments hosting the content created, funded, or of interest to them in repositories that would make the content openly available to the world (Lewis, September 2017, 1).

To this end, the Libraries will operationalize their plans to invest more in unique and open collections, and collaborate with partners to expand access to and use of scholarship. They will articulate, communicate and apply standards for provider practices to determine which 
relationships they pursue. This process of vendor review and reallocation of acquisitions dollars will be conducted in partnership with those producing the research outputs, as well as other libraries and open access support organizations. Future contract negotiations with vendors and publishers will prioritize financial investment in the systems, services and terms of agreement, such as retention of author's rights, text and data mining and resource sharing, that advance scholarship, and ensure open access to it. As the Libraries work in collaboration with campus scholars and other organizations to provide financial support and streamlined workflow systems for OA publication and discovery, the trend towards OA publication will accelerate. Research outputs and open educational resources produced, provided and preserved on campus will become part of a much greater open scholarly commons.

David Bollier describes "commoning" as "acts of mutual support, conflict, negotiation, communication and experimentation that are needed to create systems to manage shared resources. This process blends production (self provisioning), governance, culture, and personal interests into one integrated system" (Bollier, 2016, 2). From their stated values of: collaborations and partnerships; diversity and inclusion; innovation and creativity; openness and transparency; and sustainability and stewardship - as well as their commitment to organizational excellence - the Libraries will build upon what they have in place: a knowledge framework that supports campus research, scholarship and education priorities. The Libraries' relationships will serve a scholarly communication system that makes the broadest possible range of content openly available and accessible.

\section{REFERENCES}


Bollier, David. 2016. "Commoning as a Transformative Social Paradigm." TheNextSystemProject, April 28. https://thenextsystem.org/commoning-as-a-transformative-social-paradigm.

Dempsey, Lorcan. 2016. "Library collections in the life of the user: two directions." LIBER Quarterly. 26(4): 338-359.

Lewis, David W. September 2017. "The 2.5\% Commitment." https://scholarworks.iupui.edu/handle/1805/14063.

Lewis, David W. August 2017. "Thinking Differently About the Money: A First Step Toward the Open Scholarly Commons." http://hdl.handle.net/1805/13774.

Reinsfelder, Thomas L. and Caitlin Pike. 2018. “Using library funds to support open access publishing through crowdfunding: Going beyond article processing charges." Collection Management, 43(2): 138-149. 